\title{
Alzheimer's disease: the end of the beginning?
}

Remarkable progress has been made toward understanding Alzheimer's disease. Hardly more than a decade ago, this affliction, that brings tragedy to so many, concerned few within the medical establishment: some neuropathologists, occasionally a psychiatrist or neurologist. For those who lived long enough to experience significant risk from dementing illness, what happened to their mental faculties was seen as an expectable consequence of age alone. Alzheimer's disease is far from conquered, but progress should be measured from starting points that have been fast receding. Moreover, the process leading to this result holds useful lessons for psychiatry generally.

\section{NEUROPATHOLOGY TO NEUROCHEMISTRY}

Medicine offers few better examples of direct exploitation of hypotheses generated by pathology. Coupling neurofibrillary tangles and senile plaques in brain tissue to clinical dementia led Alois Alzheimer to delimit a specific condition, Alzheimer's disease. Uneventful decades followed until Sir Martin Roth and his colleagues at Newcastle began building on Alzheimer's foundation by demonstrating a direct relationship between his brain lesions and mental decline recorded in life (Blessed et al. 1968). That research programme also related cholinergic neurotransmission to clinical dementia (Perry et al. 1968). Soon it became clear that cholinergic deficits were consistent features of Alzheimer's disease (Davies, 1979; Bowen et al. 1983), and that the affected cell bodies were located in the basal forebrain (Whitehouse et al. 1982). While brains having Alzheimer's disease display several other neurochemical abnormalities, cholinergic markers, in particular choline acetyltransferase, are the most consistently affected. This demonstrated deficiency in cholinergic transmission provided a rationale for attempts at pharmacological intervention aimed at increasing neuronal access to acetylcholine. None has so far proved effective, but compared to the mostly accidental development of earlier psychiatric drug treatments, the logic of the attempts is a landmark of maturing science.

\section{NEUROPATHOLOGY TO MOLECULAR、GENETICS}

That familial transmission of Alzheimer's disease occurred had been demonstrated by the late Torsten Sjögren and his colleagues (Sjögren $e t$ al. 1953). Over the past decade, that work has been widely repeated and refined. The reported empirical risks to relatives have been remarkably consistent for persons and families averaging more youthful onset of illness - up to age 70 or 75 (Heston et al. 1981; Heyman et al. 1984; Breitner \& Folstein, 1983). Many of these families suggest autosomal dominance: close to $50 \%$ of first-degree relatives are affected and males and females are equally at risk. However, onset of illness at older ages introduces ambiguous evidence and divergent interpretations of it. The problem underlying this cannot be minimized: the diagnosis of Alzheimer's disease still requires examination of brain tissue by a competent neuropathologist. Clinical diagnoses at advanced ages, often when other chronic diseases are known to be present, are especially vexing. Moreover, Alzheimer's disease becomes so prevalent $-20-25 \%$ of persons over age 80-85 - that chance accumulations of cases becomes probable. Some investigators effectively stop counting older onset cases unless an autopsy is done, while others remain confident of clinical

\footnotetext{
' Address for correspondence: Dr Leonard L. Heston, Department of Psychiatry, University of Minnesota, Minneapolis, Minnesota 55455, USA.
} 
diagnoses. The latter approach tends to find transmission by autosomal dominance accounting for nearly all Alzheimer's disease (Mohs et al. 1987). In contrast, those less certain about diagnosis in late-onset cases tend to report smaller recurrence risks and more apparently sporadic cases (Heston et al. 1981; Heyman et al. 1984).

Family studies had a further important result, the rediscovery of the relationship between Alzheimer's disease and Down's syndrome. All Down's cases over age 40 coming to autopsy have had the plaques and tangles of Alzheimer's disease (Malamud, 1972). This critical clue, together with the family studies, set the stage for the advent of molecular genetics.

\section{MOLECULAR STUDIES}

Molecular investigations have followed two pathways. Again, one flowed with exemplary logic from pathology; the amyloid core of the senile plaque. The amino acid sequence of amyloid, a peptide, was worked out by Glenner \& Wong (1984). Soon, an oglionucleotide was constructed based on that sequence which was found to hybridize to DNA from chromosome 21, the trisomic chromosome in Down's (Goldgaber et al. 1987; Kang et al. 1987; Tanzi et al. 1987a; Robakas et al. 1987). The other pathway began with the family studies. Genetic linkage was sought using a basic tool of molecular genetics, the fragment-length polymorphism. Although large families of suitable composition for which diagnosis was reasonably established are rare, linkage between disease and DNA fragments from chromosome 21 was reported (St George-Hyslop et al. (1987a). It was a mild surprise that the amyloid segment of chromosome 21 was not linked to the Alzheimer segment (Tanzi et al. 1987 b).

As is proving typical of linkage reports in psychiatry, subsequent linkage studies have yielded mixed results. Two groups have reported in meetings that they have been unable to confirm linkage to chromosome 21. A third group described mildly positive results. Such divergence should be expected. Some will surely prove due to heterogeneity, and some to the statistics of linkage, which are extremely sensitive to diagnostic error. Today, the original report of linkage to 21 , though beleaguered, is standing. But that is not the important conclusion. Molecular studies have demonstrated that the tools are in hand that will eventually delimit DNA segments associated with Alzheimer's disease. The question is when.

\section{AETIOLOGICAL THEORIES}

Most current theories of pathogenesis invoke hyperexpression of chromosome 21's DNA. In Down's this is a sufficient cause. The $50 \%$ excess of genomic DNA yields roughly $50 \%$ excess product (Epstein, 1986). The DNA is excess, but it is normal - 'wild type' in genetic terms. Therefore its products are normal and it is the excess product per se that must be causal in Down's. Current aetiological theories attempting to account for disease in disomic persons posit an analogous excess of chromosome-21 products: amyloid could be one such. One hypothesis to account for excess product states that a 'partial trisomy', a submicroscopic excess of chromosome-21 DNA, may be present in Alzheimer's disease. Though searched for assiduously, especially by Schweber (1985), excess DNA has not been demonstrated. Another possible mechanism, gene duplication, has been excluded (St George-Hyslop et al. 1987b). As a final current alternative, the causal DNA might contain a transregulatory segment acting on disomic chromosome-21 DNA to increase production of normal products. Such a pathogenic segment might be on any chromosome, including 21 (Heston \& Morris, 1986).

\section{FUTURE DIRECTIONS}

After causal DNA segments are isolated, the next steps will be working out the links between DNA, its aberrant products or aberrant regulatory sequences, and Alzheimer's disease as we now understand it. Here, as elsewhere in psychiatry, this entails understanding the interplay between 
environment and DNA. The concordance rate for Alzheimer's disease in identical twins is hardly $50 \%$, perhaps less (Nee et al. 1987), so environment is demonstrably critical. Yet, as with other psychiatric illness, we would not know how to manipulate environment so as to produce or prevent disease in a person known to possess the causal DNA. As the physical chemistry of DNA advances, ignorance of environment looms as our overriding deficiency.

I sometimes reflect on a pair of 62-year-old identical twins from a high risk Alzheimer family that I have been following. One twin, now bedfast, has had Alzheimer's disease for 11 years, while her co-twin has remained perfectly well. There have been no changes in the co-twin's serial CAT scans or EEGs, and her psychometric test scores have improved, presumably with practice. Of course, the discordance in disease may not be an effect of environment as we usually think of it. The well twin may have had simple good luck, a favourable draw in some stochastic process, perhaps one involving gene inactivation. But whatever happened, or did not happen, to her is associated with ideal mental well-being, despite known possession of a DNA segment associated with early onset Alzheimer's disease. Moreover, her good health does not depend on drugs or any other medical imposition on normal life. When we understand nature's rules, that result should be attainable for all of those at risk - which is nearly all of us.

LEONARD L. HESTON

\section{REFERENCES}

Blessed, G., Tomlinson, B. E. \& Roth, M. (1968). The association between quantitative measures of dementia and of senile change in the cerebral grey matter of elderly subjects. British Journal of Psychiatry 114, 797-811.

Bowen, D. M., Allen, S. J., Benton, J. S., Goodhardt, M. J., Haan, E. A., Palmer, A. M., Sims, N. R., Smith, C. C. T., Spillane, J. A., Esiri, M. M., Snowden, J. S., Wilcock, G. K. \& Davidson, A. N. (1983). Biochemical assessment of serotonergic and cholinergic dysfunction and cerebral atrophy in Alzheimer's disease. Journal of Neurochemistry 41, 266-271.

Breitner, J. C. S. \& Folstein, M. S. (1984). Familial Alzheimer dementia: a prevalent disorder with specific clinical features. Psychological Medicine 14, 63-80.

Davies, P. (1979). Neurotransmitter-related enzymes in senile dementia of the Alzheimer type. Brain Research 171, 319-327.

Epstein, C. J. (1986), Consequences of Chromosome Imbalance. Principles, Mechanisms, and Models. Cambridge University Press: New York.

Glenner, G. G. \& Wong, C. W. (1984). Alzheimer's disease and Down's syndrome: sharing of a unique cerebrovascular amyloid vascular protein. Biochemical and Biophysical Research Communications 122, 1131-1135.

Goldgaber, D., Lerman, M. I., McBride, O. W., Saffiotti, U. \& Gajdusek, D.C. (1987). Characterization and chromosomal localization of cDNA encoding brain amyloid of Alzheimer's disease. Science 235, 877-880.

Heston, L. L. \& Morris, M. (1986). Family studies in Alzheimer's dementia. Results and prospects. Canadian Journal of Neurological Sciences 13, 432-434 (Suppl.).

Heston, L. L., Mastri, A. R., Anderson, V. E. \& White, J. (1981). Dementia of the Alzheimer type: clinical genetics, natural history, and associated conditions. Archives of General Psychiatry 38, 1085-1090.

Heyman, A., Wilkinson, W. E., Hurwitz, B. H., Schmechel, D., Sigmon, A. H., Weinberg, T., Helms, M. J. \& Swift, M. (1983). Alzheimer's disease: genetic aspects and associated clinical disorders. Annals of Neurology 14, 507-515.

Kang, J., Lemaire, H. G., Uterbeck, A., Salbaum, J. M., Masters, C. L., Grzeschik, K. H., Multhaup, G., Beyreuter, K. \& Muller-Hill, B. (1987). The precursor of Alzheimer's disease amyloid $\beta$-protein resembles a cell-surface receptor. Nature 325, 733-736.
Malamud, N. (1972). Neuropathology of organic brain syndromes associated with ageism. In Aging and the Brain ed C. M. Gaits, pp. 63-87. Plenum Press: New York.

Mohs, R. C., Breitner, J. C., Silverman, J. M. \& Davis, K. L. (1987). Alzheimer's disease. Morbid risk among first degree relatives approximates $50 \%$ by 90 years of age. Archives of General Psychiatry 44, 405-408.

Nee, L. E., Eldridge, R., Sunderland, T., Thomas, C. B. Katz, D., Thompson, K. E., Weingartner, H., Weiss, B. A. \& Julian, C. R. (1987). Dementia of the Alzheimer type: clinical and family study of 22 twin pairs. Neurology 37, 359-363.

Perry, E. K., Tomlinson, B. E., Blessed, K., Bergman, K., Gibson, P. H. \& Perry, R. H. (1978). Correlation of cholinergic abnormalities with senile plaques and mental test scores in senile dementia. British Medical Journal ii 1457-1459.

Robakas, N. K., Ramakkrishna, A. N., Wolfe, G. \& Wisniewski, H. M. (1987). Molecular cloning and characterization of a cDNA encoding the cerebrovascular and the neuritic plaque amyloid peptides. Proceedings of the National Academy of Sciences of the USA 84, 1910-1914.

Schweber, M. (1985). A possible unitary genetic hypothesis for Alzheimer's disease and Down's syndrome. Molecular structure of the number 21 chromosome and Down's syndrome. Annals of the New York Academy of Science 450, 223-238.

Sjögren, T., Sjögren, H. \& Lundgren, A. G. H. (1953). Morbus Alzheimer and morbus Pick: a genetic clinical and pathoanatomical study. Acta Psychiatrica Neurologica Scnadinavica, suppl. 92.

St George-Hyslop, P. H., Tanzi, R. E., Polinsky, R. J., Haines, J. L., Nee, L., Watkins, P. C., Myers, R. H., Feldman, R. G., Pollen, D., Drachman, D., Growdon, J., Bruni, A., Foncin, J.-F., Salmon, D., Frommelt, P., Amaducci, L., Sorbi, S., Piacentini, S., Stewart, G. D., Hobbs, W. J., Conneally, P. M. \& Gusella, J. F. (1987a). The genetic defect causing familial Alzheimer's disease maps on chromosome 21. Science 235, 885-890.

St George-Hyslop, P. H., Tanzi, R. E., Polinsky, R. J., Neve, R. L., Pollen, D., Drachman, D., Growdon, J., Cupples, L. A., Nee, L., Myers, R. H., O'Sullivan, D., Watkins, P. C., Amos, J. A., Deutsch, C. K., Bodfish, J. W., Kinsbourne, M., Feldman, R. G., Bruni, A., Amaducci, L., Foncin, J.-F. \& Gusella, J. F. (1987 b). Absence of duplication of chromosome 21 genes in familial and sporadic Alzheimer's disease. Science 238, 664-666.

Tanzi, R. E., Gusella, J. F., Watkins, P. C., Bruns, G. A. P., St 
George-Hyslop, P. H., van Keuren, M. L., Patterson, D., Pagan, S., Kurnit, D. M. \& Neve, R. L. (1987a). Amyloid $\beta$-protein gene: cDNA, mRNA distribution, and genetic linkage near the Alzheimer locus. Science 235, 880-884.

Tanzi, R. E., St George-Hyslop, P. H., Haines, J. L., Polinsky, R. J., Nee, L., Neve, R. L., McClatchey, A. I., Conneally, P. M. \& Gusella, J. F. (1987b). The genetic defect in familial Alzheimer's disease is not tightly linked to the amyloid $\beta$-protein gene. Nature $329,666-669$.

Whitehouse, P. J., Price, D. L., Struble, R. G., Clark, A. W., Coyle, J. T. \& De Long, M. R. (1982). Alzheimer's disease and senile dementia: loss of neurons in the basal forebrain. Science 215, 1237-1239. 